OPEN ACCESS

Edited by:

Yong Xiao,

Institute of Urban Environment (CAS),

China

Reviewed by:

Xianhua Liu,

Tianjin University, China

Yifeng Zhang,

Technical University of Denmark

Denmark

*Correspondence:

Jianqiang Zhao

626710287@qq.com

Specialty section:

This article was submitted to

Microbiotechnology, Ecotoxicology

and Bioremediation

a section of the journal

Frontiers in Microbiology

Received: 09 September 2016 Accepted: 03 January 2017

Published: 19 January 2017

Citation:

Zhao J, Wu J, Li X, Wang S, Hu B and Ding $X$ (2017) The Denitrification

Characteristics and Microbial

Community in the Cathode of an MFC with Aerobic Denitrification at High

Temperatures. Front. Microbiol. 8:9. doi: 10.3389/fmicb.2017.00009

\section{The Denitrification Characteristics and Microbial Community in the Cathode of an MFC with Aerobic Denitrification at High Temperatures}

\author{
Jianqiang Zhao ${ }^{1,2 *}$, Jinna $\mathrm{Wu}^{1}$, Xiaoling $\mathrm{Li}^{3}$, Sha Wang ${ }^{1}$, Bo $\mathrm{Hu}^{3}$ and Xiaoqian Ding ${ }^{1}$ \\ ${ }^{1}$ School of Environmental Science and Engineering, Chang'an University, Xi'an, China, ${ }^{2}$ Key Laboratory of Subsurface \\ Hydrology and Ecological Effect in Arid Region of Ministry of Education, Xi'an, China, ${ }^{3}$ School of Civil Engineering, Chang'an \\ University, Xi'an, China
}

Microbial fuel cells (MFCs) have attracted much attention due to their ability to generate electricity while treating wastewater. The performance of a double-chamber MFC with simultaneous nitrification and denitrification (SND) in the cathode for treating synthetic high concentration ammonia wastewater was investigated at different dissolved oxygen (DO) concentrations and high temperatures. The results showed that electrode denitrification and traditional heterotrophic denitrification co-existed in the cathode chamber. Electrode denitrification by aerobic denitrification bacterium (ADB) is beneficial for achieving a higher voltage of the MFC at high DO concentrations (3.0-4.2 mg/L), while traditional heterotrophic denitrification is conducive to higher total nitrogen (TN) removal at low DO $(0.5-1.0 \mathrm{mg} / \mathrm{L})$ concentrations. Under high DO conditions, the nitrous oxide production and TN removal efficiency were higher with a $50 \Omega$ external resistance than with a $100 \Omega$ resistance, which demonstrated that electrode denitrification by ADB occurred in the cathode of the MFC. Sufficient electrons were inferred to be provided by the electrode to allow ADB survival at low carbon:nitrogen ratios $(\leq 0.3)$. Polymerase chain reaction-denaturing gradient gel electrophoresis (PCR-DGGE) results showed that increasing the DO resulted in a change of the predominant species from thermophilic autotrophic nitrifiers and facultative heterotrophic denitrifiers at low DO concentrations to thermophilic ADB at high DO concentrations. The predominant phylum changed from Firmicutes to Proteobacteria, and the predominant class changed from Bacilli to Alpha, Beta, and Gamma Proteobacteria.

Keywords: aerobic denitrifying bacteria, dissolved oxygen, microbial fuel cell, predominant species, simultaneous nitrification and denitrification

\section{INTRODUCTION}

Microbial fuel cells (MFCs) have gained widespread attention as an innovative wastewater treatment and energy recovery technology that combines sewage purification and electricity production (Janicek et al., 2014; Li et al., 2014). Recent studies have shown that nitrate and nitrite can be removed from wastewater as electron acceptors in the cathode of an MFC through electrochemical reduction or autotrophic denitrification (Zhang and Angelidaki, 2012). Several 
developments of nitrogen removal with MFCs have been achieved with various designs and configurations (He et al., 2009; Virdis et al., 2010; Zhang and Angelidaki, 2013). In the studies of Bernardino Virdis et al., the cathodic process with in situ nitrification through specific aeration attained simultaneous nitrification and denitrification (SND) in one half-cell (Virdis et al., 2010). Although, nitrogen recovery with MFCs through $\mathrm{NH}_{3}$ stripping has been successfully developed to simultaneously produce energy and recover ammonium (Kuntke et al., 2012; Zhang and Angelidaki, 2015), SND in cathode of MFCs and its some new biochemical mechanisms still remain valuable to explore. Studies of simultaneous phenol removal, nitrification and denitrification using MFCs have indicated that phenoldegrading bacteria, nitrifiers, and denitrifiers in the aerobic cathode chamber are responsible for phenol oxidation, aerobic nitrification and aerobic denitrification, respectively (Feng et al., 2015). The impact of dissolved oxygen (DO) on the SND process in the cathode of an MFC has also been investigated comprehensively (Virdis et al., 2010). Because the bacteria may evolve during long-term operation, the impact of DO on the performance of cathode denitrification is different from that over shorttime periods. The SND mechanism in the aerobic cathode chamber is complex and remains unclear.

In the traditional theory of biological nitrogen removal, ammonia is first oxidized to nitrate by autotrophic nitrifiers, and the nitrate is then reduced to nitrogen by heterotrophic denitrifiers (Robertson and Kuenen, 1984). Based on the different growth conditions of nitrifiers and denitrifiers, the traditional theory of biological nitrogen removal makes a strict distinction between the nitrification and denitrification processes. The former is carried out under aerobic conditions, while the latter requires anaerobic conditions. Therefore, it is impossible for the two reactions to occur simultaneously in the same reactor. However, the discovery of heterotrophic nitrifiers and aerobic denitrifiers has made it possible for nitrification and denitrification to occur simultaneously (Huang et al., 2013; Li et al., 2015). Heterotrophic nitrifying bacteria can produce hydroxylamine, nitrite and nitrate by nitrification using organic carbon as a source for growth, and most of these bacteria can also directly convert nitrifying products to nitrogen gas through the process of aerobic denitrification (Papen and Von Berg, 1998). Aerobic denitrification bacterium (ADB) can use aerobic denitrifying enzymes for denitrification under aerobic conditions (Robertson et al., 1988; Bell and Ferguson, 1991).

In the 1980s, Robertson and Kuenen (1984) isolated the aerobic denitrifiers Thiosphaera pantotropha, Pseudomonas spp. and Alcaligenes faecalis for the first time and reported the existence of the aerobic denitrifying enzyme system (Robertson et al., 1988). They also confirmed that the growth rate of Paracoccus denitrificans will be higher in the presence of $\mathrm{O}_{2}$ and $\mathrm{NO}_{3}^{-}$. Bell and Ferguson (1991) demonstrated that aerobic denitrifying enzymes were more active in the presence of $\mathrm{O}_{2}$, and Meiberg et al. (Ferguson, 1994) reported that denitrification could be carried out by Hyphomicrobium $X$ under aerobic conditions. Many studies have proved the existence of $\mathrm{ADB}$ (Chen et al., 2003; Kim et al., 2005) and found that some denitrifiers survive under high $\mathrm{O}_{2}$ concentration conditions
(Takaya et al., 2003). Certain groups of bacteria, such as Bacillus, P. putida, P. stutzeri, Hydrogenophaga, and Achromobacter, have been shown to have heterotrophic nitrification and aerobic denitrification abilities and to convert ammonium to nitrogen aerobically in the cathode chamber of an MFC (Feng et al., 2015). Nevertheless, few attempts have been made to attain SND at high temperatures. Because some wastewater, similar to sludge digestion solutions and effluents of anaerobic reactors that treat landfill leachate, contains high concentrations of ammonia at high temperatures, studies of SND and the performance of ADB in the cathode of an MFC at high temperatures are important.

This study investigated the performance of a double-chamber MFC with SND in the cathode at fluctuating high temperatures $\left(36-48^{\circ} \mathrm{C}\right)$. Synthetic wastewater that contained organics and high concentrations of ammonia was fed into the anode chamber and then turned into the cathode chamber. The denitrification characteristics were studied by comparing scenarios with two ranges of DO concentrations (0.5-1.0 and 3.0-4.2 mg/L) and scenarios with two external resistances (50 and $100 \Omega$ ) at high DO concentrations. The microbial communities at the two DO concentrations in the cathode of the MFC were identified with polymerase chain reaction-denaturing gradient gel electrophoresis (PCR-DGGE) to explore the evolution of the dominant bacteria.

\section{MATERIALS AND METHODS}

\section{Experimental Set-up}

The MFC device was constructed with cathode and anode chambers. The anode and cathode chambers were both made of organic glass tube $8 \mathrm{~cm}$ high and $9 \mathrm{~cm}$ in diameter and had an effective volume of $0.452 \mathrm{~L}$ (Figure 1). Each chamber used a carbon brush as the electrode. The two chambers were separated by a proton exchange membrane (Nafion 117) and placed in a water bath. The temperature was initially set to $31 \pm 1^{\circ} \mathrm{C}$ and then changed to a dynamic temperature $\left(36-48^{\circ} \mathrm{C}\right)$ later in the operation. The cathode and anode chambers were connected with a manual variable resistor (0-9999 $\Omega$ ) to close the circuit. The cathode chamber was exposed to air, and blast aeration was used. The influent was injected into the anode chamber using a peristaltic pump (YZ1515X, Lange), and the effluent from the anode was fed into the cathode chamber.

\section{Influent Component}

The influent for the MFC reactor was an artificially simulated high strength ammonia sludge digestion solution with components of $0.38 \mathrm{~g} / \mathrm{L} \mathrm{CH} \mathrm{CH}_{3} \mathrm{COONa}, 2.708 \mathrm{~g} / \mathrm{L} \mathrm{NH}_{4} \mathrm{HCO}_{3}$, $0.33 \mathrm{~g} / \mathrm{L} \quad \mathrm{KH}_{2} \mathrm{PO}_{4}, 1 \mathrm{~g} / \mathrm{L} \quad \mathrm{K}_{2} \mathrm{HPO}_{4} \cdot 3 \mathrm{H}_{2} \mathrm{O}, 1 \mathrm{~g} / \mathrm{L} \quad \mathrm{KCl}, 1.5 \mathrm{~g} / \mathrm{L}$ $\mathrm{NaHCO}_{3}, 0.016 \mathrm{~g} / \mathrm{L} \mathrm{CaCl}$, and $1 \mathrm{ml} / \mathrm{L}$ trace nutrient solution. $\mathrm{CH}_{3} \mathrm{COONa}$ and $\mathrm{NH}_{4} \mathrm{HCO}_{3}$ were added to maintain the chemical oxygen demand (COD) and the ammonia nitrogen concentrations in the influent at 300 and $480 \mathrm{mg} / \mathrm{L}$, respectively.

\section{Start-up and Operation}

The anode and cathode chambers of the MFC were inoculated with aerobic sludge from the aeration tank of the Fourth Wastewater Treatment Plant in Xi'an, China. Before operating 


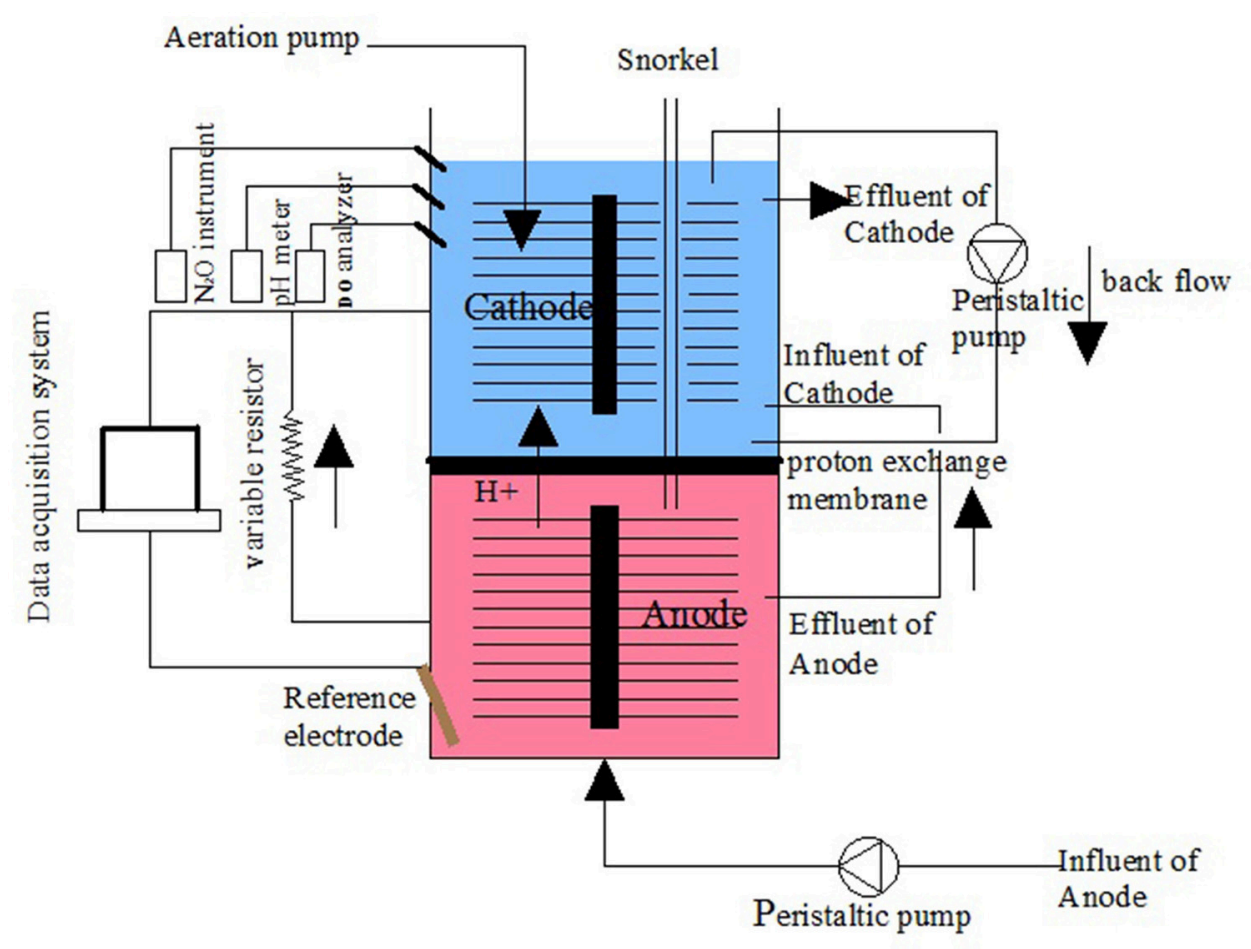

FIGURE 1 | Schematic of the double chamber MFC.

the MFC, the anode and cathode were soaked in the inoculation sludge for $24 \mathrm{~h}$. Once the reactor was filled with synthetic wastewater, the MFC entered the stage of static culture without the influent while keeping the cathode aerated and the inner circuit open. The concentrations of $\mathrm{DO}, \mathrm{NO}_{3}^{-}-\mathrm{N}, \mathrm{NO}_{2}^{-}-\mathrm{N}$, and $\mathrm{NH}_{4}^{+}-\mathrm{N}$ and the $\mathrm{pH}$ of the cathode electrolyte were measured daily. After more than half of the original $\mathrm{NH}_{4}^{+}-\mathrm{N}$ was converted to $\mathrm{NO}_{2}^{-}-\mathrm{N}$ in the cathode electrolyte, the aeration mode was changed from continuous to intermittent $(2 \mathrm{~h}$ aeration and $2 \mathrm{~h}$ static), and the wastewater was pumped continuously into the anode chamber with hydraulic retention times (HRTs) of $10.4 \mathrm{~h}$ for both the cathode and the anode chambers. After a period of continuous operation, stable partial nitrification was obtained in the cathode chamber of the MFC. An external resistance of $100 \Omega$ was then connected, following which the operation of MFC with SND started.

\section{Analytical Method}

The anode potential was monitored with a saturated calomel electrode (SCE, $+0.242 \mathrm{~V}$ standard hydrogen electrode; Type 232, Leici Instrument Factory, Shanghai, China). $\mathrm{NO}_{3}^{-}-\mathrm{N}, \mathrm{NO}_{2}^{-}-$ $\mathrm{N}$ and $\mathrm{NH}_{4}^{+}-\mathrm{N}$ were measured according to Standard Methods for the Examination of Water and Wastewater (Clesceri et al., 1998). DO was determined using a Hach-HQ30d DO analyzer $(\mathrm{HACH}$, America). The voltage and anode potential were monitored and recorded using a PCI1717 voltage collector (Yanhua Company, Shenzhen, China). An $\mathrm{N}_{2} \mathrm{O}$ microsensor (Unisense, Denmark) was used for the $\mathrm{N}_{2} \mathrm{O}$ analysis.
Samples from the biofilm of the cathode were collected on day 27 and day 83 to investigate the microbial community with DGGE, and DNA was extracted using a fast DNA spin kit (SK8233) for soil according to the manufacturer's instructions. The bacterial 16S rRNA genes were amplified by PCR with the universal primers F357-GC (5'-CGCCCG CCGCGCCCCGCGCCCGGCCCGCCGCCCCGCCCCCCTAC GGGAGGCAGCAG-3') and R518 (5'-ATTACCGCGGCTGC TGG-3'). A polyacrylamide gel (8\%) with a $30-60 \%$ denaturing gradient was used to separate the PCR products $(7 \mathrm{~mol} \mathrm{~L}-1$ urea and $40 \%$ formamide comprising $100 \%$ denaturant), which were analyzed using DGGE technology and washed with ultrapure water to flush the gel and dye. Eight representative DGGE strips were selected by a clean scalpel and transferred to a $1.5 \mathrm{~mL}$ centrifuge tube. The target DNA fragments were then excised and reamplified using the primer sets F357 (5'-CCTACGGGAGGCAGCAG-3') and R518 (5'-ATTACCGCGGCTGCTGG- $3^{\prime}$ ), and the obtained sequence was matched with the Seqmatch database for sequence alignment. The homology information of each strip was obtained by Sangon Biotech Co., Ltd. (Shanghai, China).

\section{RESULTS AND DISCUSSION \\ Performance of the MFC}

The results of the continuous operation test are shown in Figure 2. 


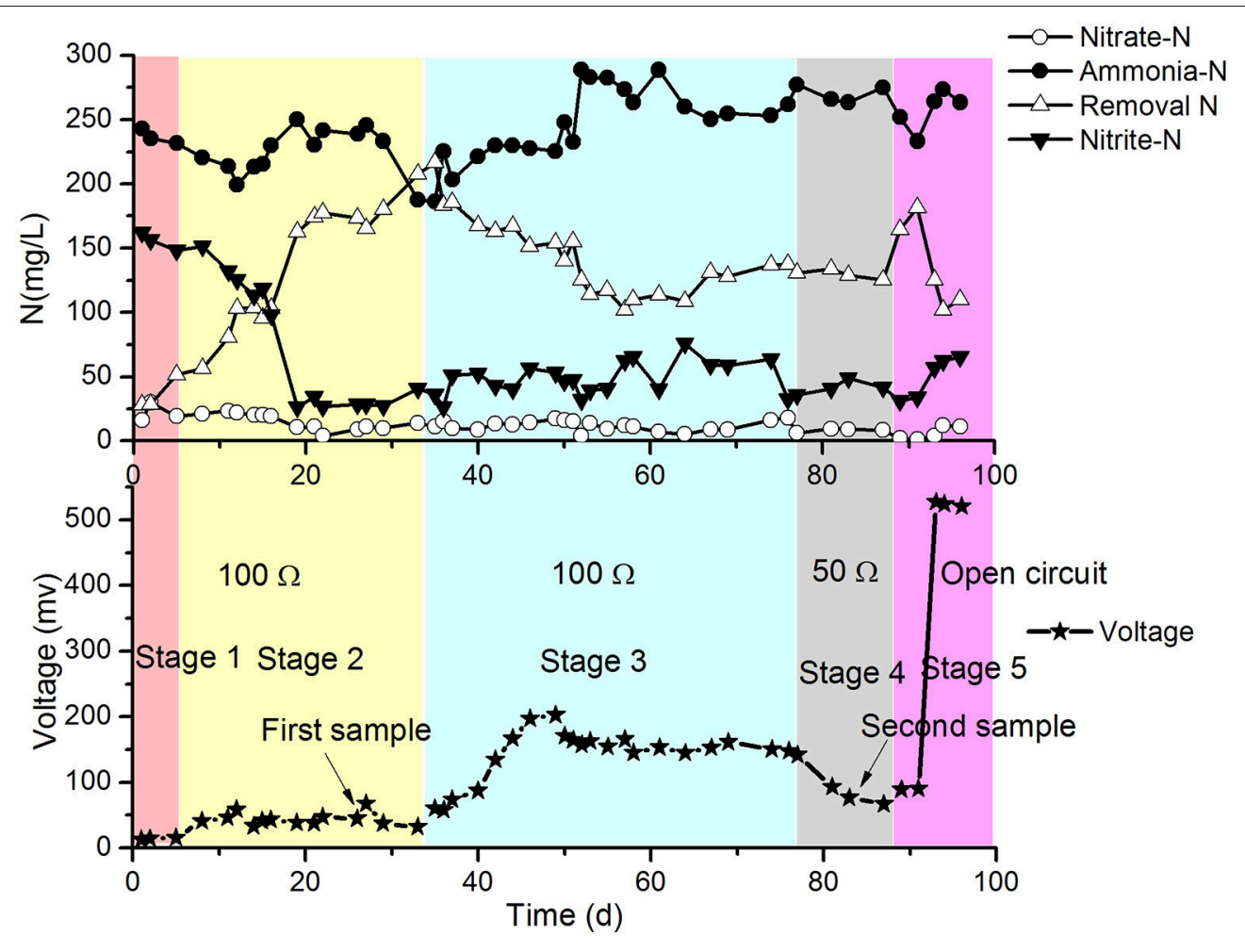

FIGURE 2 | Profiles of $\mathrm{NH}_{4}^{+}-\mathrm{N}, \mathrm{NO}_{2}^{-}-\mathrm{N}$ and $\mathrm{NO}_{3}^{-}-\mathrm{N}$ in the effluent of the cathode chamber and voltages of the MFC.

In stage 1 (first 5 days of the test), the MFC with SND was operated at $31 \pm 1{ }^{\circ} \mathrm{C}, 100 \Omega$ resistance and intermittent aeration ( $2 \mathrm{~h}$ aeration and $2 \mathrm{~h}$ static), and the $\mathrm{DO}$ of the catholyte was $0.5-1.0 \mathrm{mg} / \mathrm{L}$. The concentrations of $\mathrm{NH}_{4}^{+}-\mathrm{N}$ and $\mathrm{NO}_{2}^{-}-\mathrm{N}$ decreased with a gradual increase in the release voltage of the MFC. However, the removal of total nitrogen (TN) was much greater than that with the electrical current of the MFC. This finding implies that the traditional heterotrophic microbial denitrification with COD was more efficient at removing nitrogen than the electrode denitrification in the cathode chamber. The moderate temperature $\left(31 \pm 1^{\circ} \mathrm{C}\right)$ and low DO $(0.5-1.0 \mathrm{mg} / \mathrm{L})$ in the cathode may be beneficial for SND with COD still present in the anode effluent.

In stage 2 (days 6-34), the temperature of the reactor increased and fluctuated over the range of $36-48^{\circ} \mathrm{C}$. The removal of TN began to increase sharply, and the concentration of $\mathrm{NO}_{2}^{-}-\mathrm{N}$ in the cathode effluent began to decrease correspondingly from the 6th day, while the voltage of the MFC increased slightly and then stabilized. This might have been due to the high temperature in the cathode $\left(36-48^{\circ} \mathrm{C}\right)$, which was harmful for the growth of normal ammonia oxidizing bacteria (AOB). Because the suitable range of temperatures for $\mathrm{AOB}$ metabolism is $20-30^{\circ} \mathrm{C}$, the nitrification rate decreased, and the $\mathrm{NO}_{2}^{-}-\mathrm{N}$ concentration decreased to approximately $30 \mathrm{mg} / \mathrm{L}$. The increase in the TN removal was mainly caused by the volatilization of ammonium at high temperature. The TN removal from the denitrification in the electrode during stage 2 was lower and similar to that at the end of stage 1 (not greater than $7 \mathrm{mg} / \mathrm{L} \cdot \mathrm{d}$ based on the MFC voltage). The biofilm was sampled, and the bacteria were identified with PCR-DGGE. The predominant species was found to be Ureibacillus thermosphaericus of the genus Ureibacillus, which grows at temperatures of $37^{\circ}$ to $60^{\circ} \mathrm{C}$ (Fortina et al., 2001).

In stage 3 (days 35-77), the reactor was set to continuous aeration instead of intermittent aeration. As a result, the DO increased to $3 \pm 0.6 \mathrm{mg} / \mathrm{L}$. The amount of TN removed per day began to decrease, but the voltage continued to increase. This might have occurred because the heterotrophic denitrification with COD as the electron donor was inhibited by the increase of DO, and the partial oxygen accepted electrons from the electrode. In stage 3, the release voltage initially increased, then dropped and finally steadied at approximately $100 \mathrm{mV}$, which was much higher than that in stage 2. The following strain sampling clearly demonstrated that the predominant species changed to aerobic denitrifiers (a detailed analysis is provided later). The curves in Figure 2 suggest that the aerobic denitrifiers might have replaced the anaerobic denitrifiers in the latter phase of stage 3. The aerobic denitrifiers appeared to be much more receptive to the electrons from the electrode than the anaerobic denitrifiers, which was determined by comparing the voltage of stage 2 with that of stage 3 , in which the effects of electron acceptance by oxygen was taken into account. In contrast, TN removal by anaerobic denitrifiers was much greater than that by aerobic denitrifiers. The heterotrophic denitrification with 
COD might have mainly caused TN removal, excluding the effect of volatilization in the cathode. Depending on the voltage, the TN removal by electrode denitrification was $8.5-9.0 \mathrm{mg} /(\mathrm{L} \cdot \mathrm{d})$, which represented only a small part of the $\mathrm{TN}$ removal in stage 3 .

The conditions in stage 4 (days 78-88) remained the same as those in stage 3 except for the change in the resistance of the MFC from 100 to $50 \Omega$. The results showed that the concentrations of $\mathrm{NH}_{4}^{+}-\mathrm{N}$ and $\mathrm{NO}_{2}^{-}-\mathrm{N}$ in the cathode effluent decreased, and the amount of TN removed increased in the latter part of this stage (Figure 2). The voltages were greater than those in stage 3, but the TN removal by electrode denitrification was $13.5-14.6 \mathrm{mg} /(\mathrm{L} \cdot \mathrm{d})$, which was greater than that in stage 3 .

\section{Electricity Production and Nitrogen Removal Performance under High DO Conditions}

The electricity production performance of the MFC under high DO conditions and different external resistances was investigated as a case study (Figures 3-5, which correspond to days 75, 82, and 97 in Figure 2, respectively). The voltage was positively related to the increase in temperature under external resistances of $50 \Omega$ and $100 \Omega$, while it was independent of the temperature under open circuit conditions. Regardless of whether the resistances were applied or an open circuit was used, the $\mathrm{N}_{2} \mathrm{O}$ emissions were always positively related to the increase in temperature, while the DO was always negatively related to the increase in temperature. The characteristics of denitrification and electricity production of the MFC can be evaluated using these factors.

The fluctuations in the concentrations of $\mathrm{DO}$ and $\mathrm{N}_{2} \mathrm{O}$ caused by the temperature (Figures 3,5 ) show that the DO fluctuation amplitude was approximately $1.2 \mathrm{mg} / \mathrm{L}$, whereas the corresponding $\mathrm{N}_{2} \mathrm{O}$ fluctuation was approximately $0.4 \mathrm{mg} / \mathrm{L}$ in the open circuit. With a $100 \Omega$ resistance, the DO and $\mathrm{N}_{2} \mathrm{O}$ fluctuation amplitudes were $1.5 \mathrm{mg} / \mathrm{L}$ and $0.3 \mathrm{mg} / \mathrm{L}$, respectively. This demonstrated that the reduction in oxygen caused by the voltage fluctuation was approximately $0.3 \mathrm{mg} \mathrm{O} / 2$, and no $\mathrm{N}_{2} \mathrm{O}$ was produced by electrode denitrification. The concentrations of $\mathrm{N}_{2} \mathrm{O}$ were similar in both scenarios $(0.7-1.1 \mathrm{mg} / \mathrm{L})$, whereas the concentrations of DO with a $100 \Omega$ resistance were $0.7-1.0 \mathrm{mg} / \mathrm{L}$, which was lower than that in the open circuit (Figures 3, 5). This indicated that the decrease in DO was dependent on the electrode reaction, while the production of $\mathrm{N}_{2} \mathrm{O}$ was independent of the electrode reaction. Using Coulomb's law, with a $100 \Omega$ resistance, the electrode reduction rate of oxygen was calculated to be 1.6$2.3 \mathrm{mg} \mathrm{O}_{2} /(\mathrm{L} \cdot \mathrm{d})$, whereas the rate of electrode reduction of nitrite to nitrogen gas was $8.5-9.0 \mathrm{mg} \mathrm{N} /(\mathrm{L} \cdot \mathrm{d})$ with no production of $\mathrm{N}_{2} \mathrm{O}$.

The fluctuations in the concentrations of DO and $\mathrm{N}_{2} \mathrm{O}$ caused by temperature (Figures 4, 5) show that the decrease of DO and the increase of $\mathrm{N}_{2} \mathrm{O}$ were both dependent on the electrode reaction. Using Coulomb's law, with a $50 \Omega$ resistance, the electrode reduction rate of oxygen was calculated to be $2.8-$ $4.4 \mathrm{mg} \mathrm{O}_{2} /(\mathrm{L} \cdot \mathrm{d})$, whereas the rate of electrode denitrification was $13.5-14.6 \mathrm{mg} \mathrm{N} /(\mathrm{L} \cdot \mathrm{d})$, in which approximately $10 \%$ of the nitrogen removed was converted to $\mathrm{N}_{2} \mathrm{O}$ and $90 \%$ was converted to nitrogen gas.
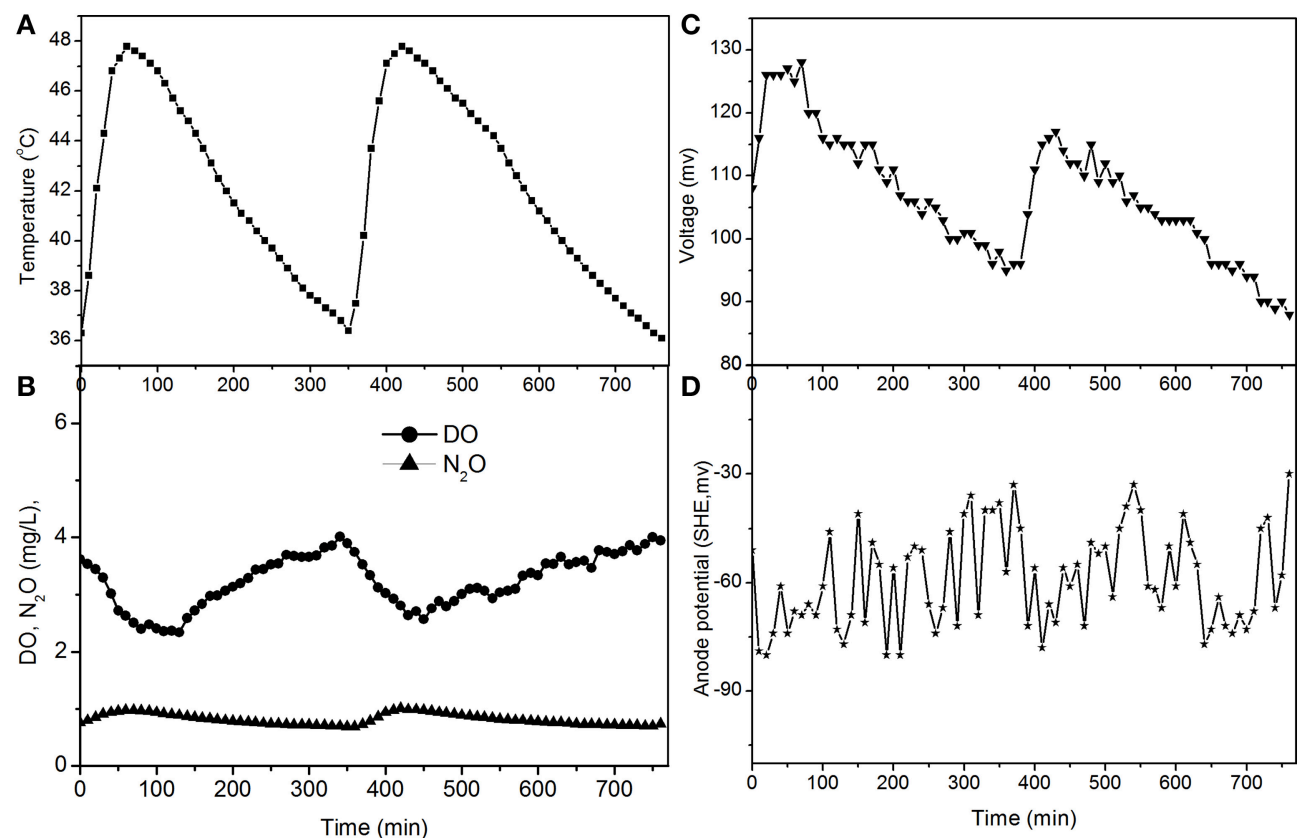

FIGURE 3 | Profiles of temperature, DO, $\mathrm{N}_{2} \mathrm{O}$, voltage, and anode potential of the MFC with $100 \Omega$ external resistance at temperatures of $36-48^{\circ} \mathrm{C}$ (day 75 in Figure 2). (A) Temperature profile; (B) DO and $\mathrm{N}_{2} \mathrm{O}$ profiles; (C) voltage profile; (D) anode potential profile. 

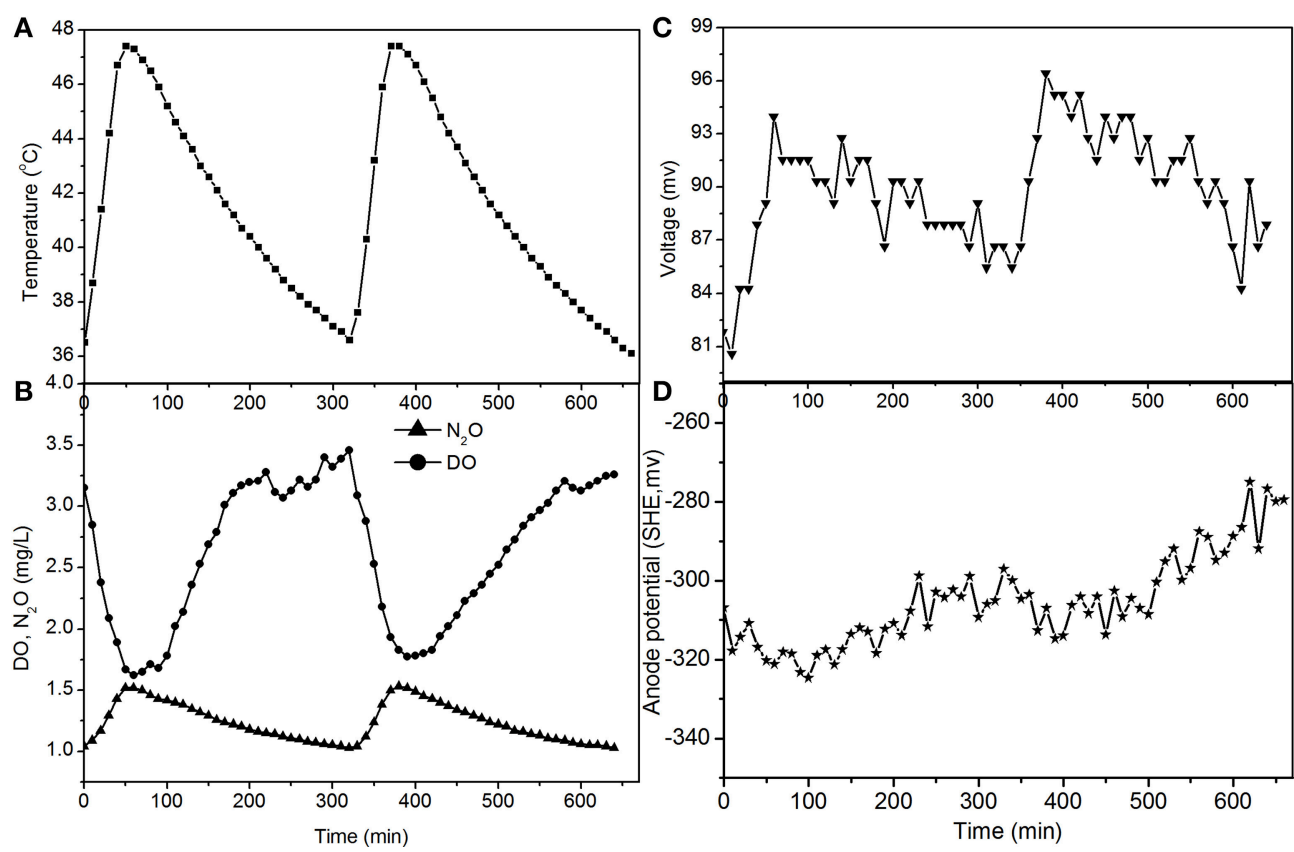

FIGURE 4 | Profiles of temperature, DO, $\mathrm{N}_{2} \mathrm{O}$, voltage, and anode potential of the MFC with $50 \Omega$ external resistance at temperatures of $36-48^{\circ} \mathrm{C}$ (day 82 in Figure 2). (A) Temperature profile; (B) DO and $\mathrm{N}_{2} \mathrm{O}$ profiles; (C) voltage profile; (D) anode potential profile.
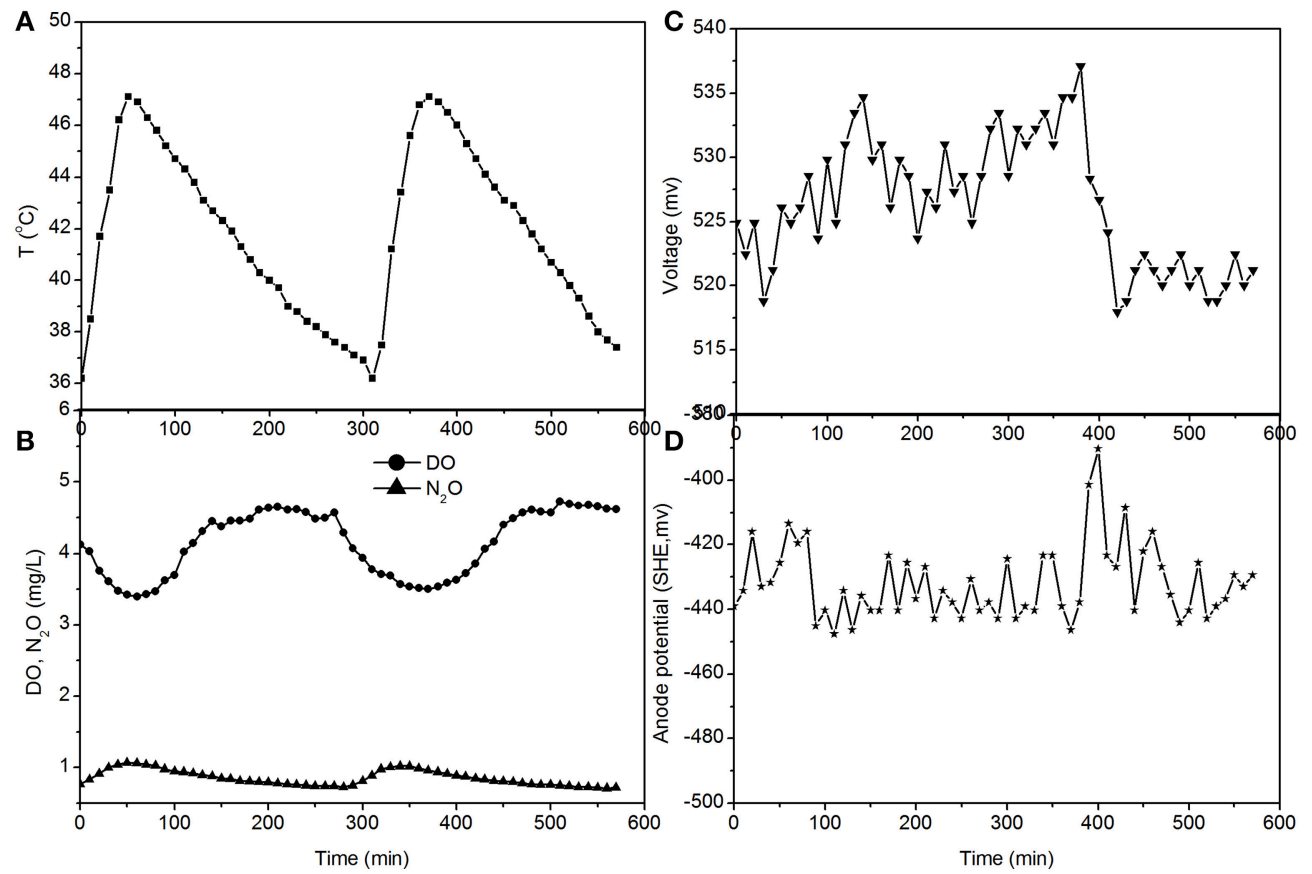

FIGURE 5 | Profiles of temperature, DO, $\mathrm{N}_{2} \mathrm{O}$, voltage, and anode potential of the MFC in open circuit at temperatures of $36-48^{\circ} \mathrm{C}$ (day 97 in Figure 2 ). (A) Temperature profile; (B) $\mathrm{DO}$ and $\mathrm{N}_{2} \mathrm{O}$ profiles; (C) voltage profile; (D) anode potential profile.

The $\mathrm{N}_{2} \mathrm{O}$ production and $\mathrm{TN}$ removal efficiencies with a $50 \Omega$ external resistance were higher than those with a $100 \Omega$ resistance, which illustrates that electrode denitrification occurred in the cathode of the MFC. These analyses indicate that both oxygen and nitrite can obtain electrons simultaneously from the electrode in the cathode of the MFC. 


\section{Performance of the Microbial Community at Low DO and High Temperature}

Biofilm samples were collected from the cathode chamber of the MFC on day 27 in stage 2 (Figure 2) and day 83 in stage 4 (Figure 2). The representative DGGE strips are shown in Figure 6. The closest species and classification of each representative band in the DGGE profile were deposited in the GenBank database (Tables 1, 2). Sequences from DGGE bands are shown in Supplementary Material.

In the first microbial identification (27th day), which corresponded to the low DO and high temperature MFC operating conditions (stage 2 in Figure 2), 12 bands were identified (Table 1). The results showed that the microbial community could be divided into 4 phyla, 4 classes and 8 genera. The phylum Firmicutes (bands 2, 3, 4, 5, 7, 8, 9, 10, and 13) was the predominant bacteria, while the phyla Ignavibacteriae (band 1), Chloroflexi (band 6) and Proteobacteria (band 14) were the subdominant groups.

Within the Firmicutes phylum, bands 2, 4, 5, 7, 8, and 9 belonged to the genus Ureibacillus, related to a species of U. thermosphaericus (similarity $91.2-100 \%$ ), which was reported to be a thermophilic bacteria $\left(37-60^{\circ} \mathrm{C}\right.$, optimum $\left.50-60^{\circ} \mathrm{C}\right)$ with heterotrophic growth in aerobic environments and no ability for nitrate reduction (Fortina et al., 2001). This species was inferred to dominate the nitrification in the cathode of the MFC under low DO and high temperature conditions.

Bands 1 and 6 belonged to the genera Ignavibacterium and Unclassified Anaerolineaceae, respectively, which grow under anaerobic conditions, are heterotrophic and cannot utilize nitrate as electron acceptors (Yamada et al., 2006; Iino et al., 2010). These species were inferred to dominate the anaerobic degradation of COD.

Bands 3 (1) and 13 belonged to the genera Geobacillus and Anoxybacillus, respectively, which grow under aerobic conditions, are heterotrophic and can reduce nitrate (Poli et al., 2006; Inan et al., 2013). These species were inferred to dominate the aerobic denitrification.

Bands 3 (2) and 10 belonged to the genera Anoxybacillus and Bacillus, respectively, which grow under anaerobic conditions, are heterotrophic and can reduce nitrate (Kim et al., 1998; Cihan et al., 2014). These two species were inferred to be responsible for the anaerobic denitrification in stage 2 (Figure 2).

Band 14 belonged to the genus Cucumibacter, which grows under aerobic conditions, is heterotrophic and cannot utilize nitrate as electron acceptors (Hwang and Cho, 2008). This species was inferred to be responsible for the aerobic degradation of COD in stage 2 (Figure 2).

\section{Performance of the Microbial Community at High DO and High Temperature}

In the second microbial identification (83th day), which corresponded to the high DO and high temperature MFC operating conditions (stage 4 in Figure 2), 7 bands were identified (Table 2). The results showed that the microbial community could be divided into 1 phylum, 7 classes and 8 genera. The phylum Proteobacteria (bands 15, 18, 24, 25, 26,

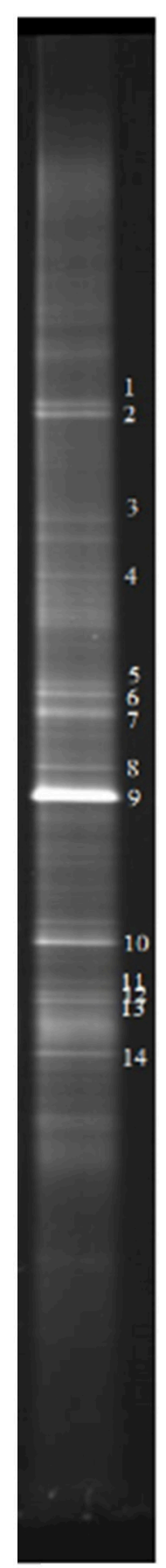

A

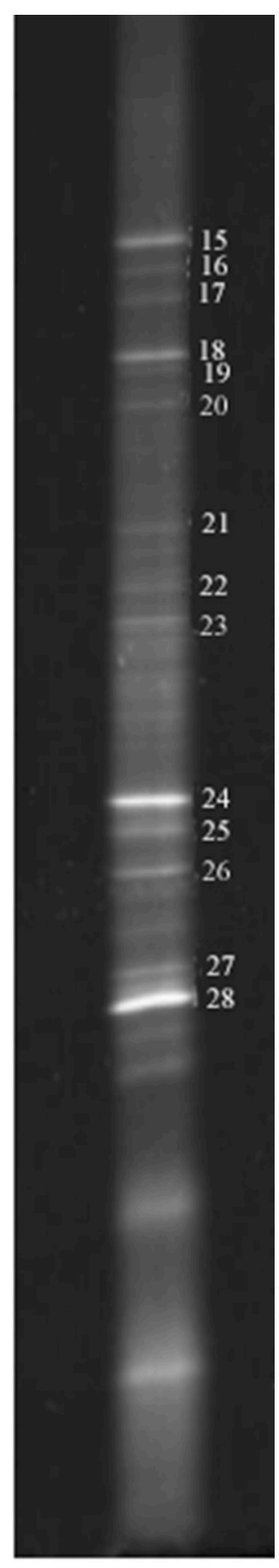

B
FIGURE 6 | Representative DGGE strips of samples. (A) Sampling at low DO levels (first sampling); (B) sampling at high DO levels (second sampling).

27, and 28) was the predominant and unique phylum. This result agrees with other studies that indicated that Proteobacteria dominates some cathodic denitrifying biofilms (Wrighton et al., 2010).

In the phylum Proteobacteria, bands 15, 24 and 27 belonged to the genera Aquamicrobium, Alishewanella, and Brachymonas 
TABLE 1 | Identification of DGGE bands under low DO conditions (the first sampling; Figure 6A).

\begin{tabular}{|c|c|c|c|c|c|}
\hline Band & Taxon & Similarity (\%) & Accession & Phylum/Genus & \\
\hline 2 & $\begin{array}{l}\text { Ureibacillus } \\
\text { thermosphaericus }\end{array}$ & 91.2 & AF403017 & $\begin{array}{l}\text { Firmicutes/ } \\
\text { Ureibacillus }\end{array}$ & $\begin{array}{l}\text { Aerobic, thermophilic, grows at } 37-60^{\circ} \mathrm{C} \text {, optimum at } 50-60^{\circ} \mathrm{C} \text {, } \\
\text { negative for nitrate reduction, anaerobic growth, acid production from } \\
\text { glucose (Fortina et al., 2001). }\end{array}$ \\
\hline 4 & As above & 100 & As above & As above & \\
\hline 5 & As above & 94.6 & As above & As above & \\
\hline 8 & As above & 92.5 & As above & As above & \\
\hline 9 & As above & 97.3 & As above & As above & \\
\hline 7 & As above & 95.7 & As above & As above & \\
\hline 10 & Bacillus sp. R-7413 & 100 & AY422985 & $\begin{array}{l}\text { Firmicutes/ } \\
\text { Bacillus }\end{array}$ & $\begin{array}{l}\text { Heterotrophic, anaerobic, nitrate reduction, optimum at } 70^{\circ} \mathrm{C}(\mathrm{Kim} \\
\text { et al., 1998) }\end{array}$ \\
\hline 13 & Anoxybacillus kaynarcensis & 97.3 & EU926955 & $\begin{array}{l}\text { Firmicutes/ } \\
\text { Anoxybacillus }\end{array}$ & $\begin{array}{l}\text { Heterotrophic, aerobic, can reduce nitrate to nitrite, grows from } \\
\text { approximately } 35 \text { to } 70^{\circ} \mathrm{C} \text {, optimum at } 60^{\circ} \mathrm{C} \text { (Inan et al., 2013). }\end{array}$ \\
\hline \multirow[t]{2}{*}{3} & Geobacillus toebii & 92.4 & EU428777 & $\begin{array}{l}\text { Firmicutes/ } \\
\text { Geobacillus }\end{array}$ & $\begin{array}{l}\text { Heterotrophic, aerobic, nitrate and nitrite reduction positive, grows from } \\
55 \text { to } 75^{\circ} \mathrm{C} \text {, optimum at } 68^{\circ} \mathrm{C} \text { (Poli et al., 2006). }\end{array}$ \\
\hline & Anoxybacillus calidus & 100 & FJ430012 & $\begin{array}{l}\text { Firmicutes/ } \\
\text { Anoxybacillus }\end{array}$ & $\begin{array}{l}\text { Facultatively anaerobic, heterotrophic, } \mathrm{N}_{2} \text { gas produced from nitrate, } \\
35-70^{\circ} \mathrm{C} \text {, optimum at } 55^{\circ} \mathrm{C} \text { (Cihan et al., 2014). }\end{array}$ \\
\hline 1 & Uncultured planctomycete & 100 & GQ35 & $\begin{array}{l}\text { Ignavibacteriae/ } \\
\text { Ignavibacterium }\end{array}$ & $\begin{array}{l}\text { Refers to a strain of Ignavibacterium album Mat9-16T, strictly } \\
\text { anaerobic, heterotrophic, grows at } 30-55^{\circ} \mathrm{C} \text {, optimum at } 45^{\circ} \mathrm{C} \text { (lino } \\
\text { et al., 2010). }\end{array}$ \\
\hline 6 & $\begin{array}{l}\text { Uncultured Chloroflexi } \\
\text { bacterium }\end{array}$ & 83.4 & JN825481 & $\begin{array}{l}\text { Chloroflexil } \\
\text { Unclassified } \\
\text { Anaerolineaceae }\end{array}$ & $\begin{array}{l}\text { Refers to a strain of Anaerolinea thermolimosa IMO- } 1 \mathrm{~T} \text {, strictly } \\
\text { anaerobic, heterotrophic bacteria, cannot utilize nitrate as electron } \\
\text { acceptors, grows at } 42-55^{\circ} \mathrm{C} \text { optimum at } 50^{\circ} \mathrm{C} \text { (Yamada et al., 2006). }\end{array}$ \\
\hline 14 & Cucumibacter marinus (T) & 96.8 & EF211830 & $\begin{array}{l}\text { Proteobacteria/ } \\
\text { Cucumibacter }\end{array}$ & $\begin{array}{l}\text { Heterotrophic aerobic bacteria, cannot reduce nitrate to nitrite, grows } \\
\text { at } 15-40^{\circ} \mathrm{C} \text {, optimum at } 30-35^{\circ} \mathrm{C}(\mathrm{H} \text { wang and Cho, 2008). }\end{array}$ \\
\hline
\end{tabular}

TABLE 2 | Identification of DGGE bands under high DO conditions (second sampling; Figure 6B).

\begin{tabular}{|c|c|c|c|c|c|}
\hline Band & Taxon & Similarity (\%) & Accession & Phylum/Genus & Properties \\
\hline 15 & $\begin{array}{l}\text { Aquamicrobium } \\
\text { aestuarii }\end{array}$ & 100 & GU199003 & $\begin{array}{l}\text { Proteobacterial } \\
\text { Aquamicrobium }\end{array}$ & $\begin{array}{l}\text { Grows at } 15-45^{\circ} \mathrm{C} \text {, optimum at } 30-35^{\circ} \mathrm{C} \text {, can reduce nitrate to nitrite, } \\
\text { strictly aerobic, heterotrophic bacteria (Jin et al., 2013). }\end{array}$ \\
\hline 25 & $\begin{array}{l}\text { Brevundimonas } \\
\text { diminuta }\end{array}$ & 98.1 & X87274 & $\begin{array}{l}\text { Proteobacteria/ } \\
\text { Brevundimonas }\end{array}$ & $\begin{array}{l}\text { Brevundimonas gen. nov, is aerobic, grows at } 30-37^{\circ} \mathrm{C} \text {, cannot reduce } \\
\text { nitrate, } 90 \% \text { of the strains are autotrophic (Segers et al., 1994). }\end{array}$ \\
\hline 26 & Uncultured bacterium & 95.7 & EF173342 & $\begin{array}{l}\text { Proteobacterial } \\
\text { Altererythrobacter }\end{array}$ & $\begin{array}{l}\text { Refers to Altererythrobacter epoxidivorans JCS350T, cannot reduce } \\
\text { nitrate, grows at } 20-40^{\circ} \mathrm{C} \text {, aerobic, optimum at } 35^{\circ} \mathrm{C} \text {, heterotrophic } \\
\text { bacteria (Kwon et al., 2007). }\end{array}$ \\
\hline 18 & $\begin{array}{l}\text { Pelomonas } \\
\text { saccharophila }(\mathrm{T})\end{array}$ & 100 & AB021407 & $\begin{array}{l}\text { Proteobacteria/ } \\
\text { Pelomonas }\end{array}$ & $\begin{array}{l}\text { Grows at } 4-40^{\circ} \mathrm{C} \text {, optimum at } 25-32^{\circ} \mathrm{C} \text {, aerobic, able to fix nitrogen and } \\
\text { show autotrophic growth with hydrogen but not photoautotrophic. } \\
\text { Glucose and acetate are utilized as carbonsources for growth but } \\
\text { negative for denitrification (Xie and Yokota, 2005). }\end{array}$ \\
\hline \multirow[t]{2}{*}{27} & $\begin{array}{l}\text { Brachymonas sp. } \\
\text { canine oral taxon } 015\end{array}$ & 89.4 & JN713175 & $\begin{array}{l}\text { Proteobacterial } \\
\text { Brachymonas }\end{array}$ & $\begin{array}{l}\text { Refers to Brachymonas denitrificans, aerobic, denitrification positive, } \\
\text { grows at } 10-40^{\circ} \mathrm{C} \text {, optimum at } 30-35^{\circ} \mathrm{C} \text { (Hiraishi et al., 1995). }\end{array}$ \\
\hline & $\begin{array}{l}\text { Comamonas } \\
\text { denitrificans }\end{array}$ & 87.8 & AF233876 & $\begin{array}{l}\text { Proteobacteria/ } \\
\text { Comamonas }\end{array}$ & $\begin{array}{l}\text { Grows at } 20,30 \text {, and } 37^{\circ} \mathrm{C} \text {, aerobic, heterotrophic, can reduce nitrate to } \\
\text { nitrogen gas and contains cd1-type nitrite reductase (the only species in } \\
\text { the genus Comamonas to do so) (Xing et al., 2010). }\end{array}$ \\
\hline 24 & Alishewanella sp. N5 & 90.1 & EU287929 & $\begin{array}{l}\text { Proteobacteria/ } \\
\text { Alishewanella }\end{array}$ & $\begin{array}{l}\text { Refers to Alishewanella aestuarii, grows at } 18-44^{\circ} \mathrm{C} \text {, aerobic, optimum at } \\
37^{\circ} \mathrm{C} \text {, can reduce nitrate to nitrite and nitrogen gas, maltose is } \\
\text { assimilated, heterotrophic bacteria (Roh et al., 2009). }\end{array}$ \\
\hline 28 & $\begin{array}{l}\text { Acinetobacter } \\
\text { gyllenbergii }(\mathrm{T})\end{array}$ & 100 & AJ293694 & $\begin{array}{l}\text { Proteobacterial } \\
\text { Acinetobacter }\end{array}$ & $\begin{array}{l}\text { Strictly aerobic, grows at } 25-37^{\circ} \mathrm{C} \text {, incapable of dissimilative } \\
\text { denitrification, heterotrophic bacteria (Nemec et al., 2009). }\end{array}$ \\
\hline
\end{tabular}

or Comamonas, respectively. These three species can grow under aerobic conditions, are heterotrophic, can utilize nitrate as electron acceptors (Hiraishi et al., 1995; Roh et al., 2009; Jin et al., 2013)and were inferred to dominate the aerobic denitrification under the high DO conditions of stage 4 (Figure 2). In particular,
Comamonas denitrificans (band 27) has been reported to switch the metabolic pathway for extracellular electron transfer (Xing et al., 2010). A species in the Comamonas genus is known to be an aerobic denitrifier, and $C$. denitrificans is the only species in the Comamonas genus that can reduce nitrate to nitrogen 
gas and contains cd1-type nitrite reductase (Gumaelius et al., 2001). Therefore, we propose that $C$. denitrificans be considered a species of $\mathrm{ADB}$. The other two species were inferred to belong to $\mathrm{ADB}$.

Bands 18, 26 and 28 belonged to the genera Pelomonas, Altererythrobacter and Acinetobacter, respectively. These three species can grow under aerobic conditions, are heterotrophic, cannot utilize nitrate as electron acceptors (Xie and Yokota, 2005; Kwon et al., 2007; Nemec et al., 2009) and might have dominated the aerobic degradation of COD in stage 4 (Figure 2).

Band 25 belonged to the genus Brevundimonas, which grows under aerobic conditions and cannot reduce nitrate, and $90 \%$ of the strains are autotrophic (Segers et al., 1994). This species was inferred to be a nitrifier.

Based on this analysis, at high temperatures, the increase in DO resulted in a change in the predominant species from thermophilic autotrophic nitrifiers and facultative heterotrophic denitrifiers at low DO concentrations to thermophilic ADB at high DO concentrations during the operation of the MFC. Three species from the genera Aquamicrobium, Brachymonas or Comamonas, and Alishewanella were inferred to belong to $\mathrm{ADB}$ and dominate the aerobic denitrification at high levels of DO. Some aerobic denitrifiers were known to be heterotrophic nitrifiers, which might benefit SND under aerobic conditions. Therefore, autotrophic nitrifiers were replaced, and $\mathrm{ADB}$ evolved to be the predominant bacteria at high DO concentrations in stage 4 of the operation. This result is similar to the study by Feng et al., who indicted that aerobic denitrification in the cathode chamber is an important pathway for nitrite and nitrate removal (Feng et al., 2015).

\section{Mechanism of the Cathode Chamber}

Based on the analysis of the composition of the microbial community and the experimental results, we speculated on the possible reactions in the cathode of the MFC (Figure 7).

The mechanism of aerobic denitrification was determined by studying the aerobic denitrifier T. pantotropha. The cooperative breathing theory, which was proposed by Robertson et al. (1988), is widely recognized as the aerobic denitrification mechanism. Cooperative breathing theory means that both $\mathrm{NO}_{3}^{-}$and $\mathrm{O}_{2}$ can be used as the final electron receptors. Therefore, the denitrifiers can transfer electrons from the reduced substance to $\mathrm{NO}_{3}^{-}$or $\mathrm{O}_{2}$, and the denitrification can occur in an aerobic environment. According to the electron transport model proposed by Willson and Bouwer (1997), both $\mathrm{NO}_{3}^{-}$and $\mathrm{O}_{2}$ can be used as the final electron receptors, while the denitrifiers can transfer electrons from the reduced substance to $\mathrm{O}_{2}$ or $\mathrm{NO}_{3}^{-}$through nitrate reductase. Moreover, a carbon source is required for $\mathrm{ADB}$. The higher the concentration of the carbon source is, the faster the aerobic denitrification rate will be (Robertson and Kuenen, 1983). Huang and Tseng (2001) indicated that the denitrification rate was highest when $\mathrm{C} / \mathrm{N}$ was 5 and decreased with increasing $\mathrm{C} / \mathrm{N}$ when $\mathrm{C} / \mathrm{N}$ was greater than 5 and acetate was used as the carbon source. However, ADB did not appear to be required at such a high $\mathrm{C} / \mathrm{N}$ ratio in our study. The influent $\mathrm{C} / \mathrm{N}$ for the cathode chamber of the MFC was less than 0.3 , possibly because the electrons provided by the electrode of the MFC were sufficient
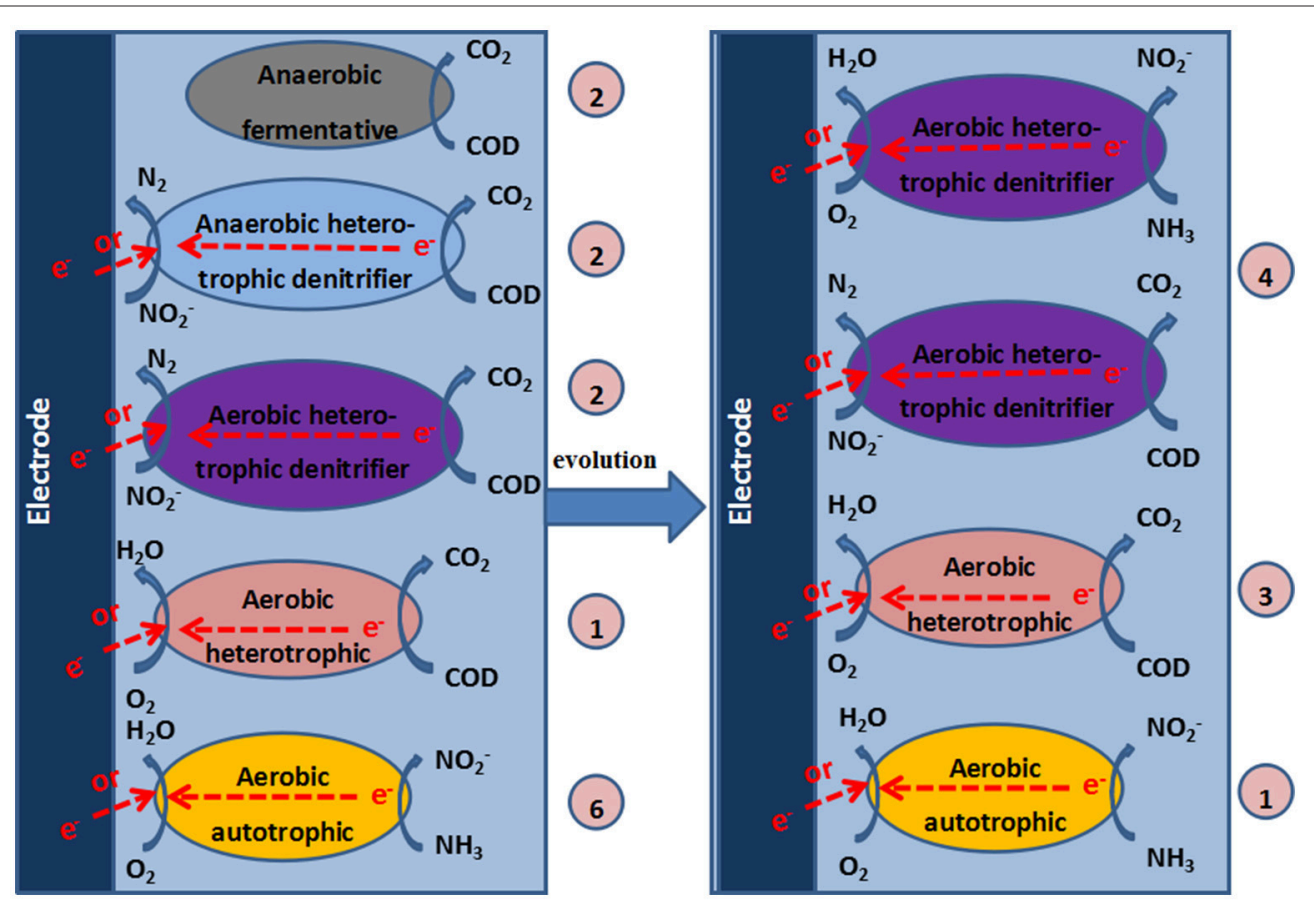

FIGURE 7 | Mechanisms in the cathode chamber of the MFC. The numbers in the circles represent the quantities of DGGE bands that correspond to the identified bacteria. 
for the growth of aerobic bacteria. The aeration cathode chamber of the MFC may be beneficial for the growth of ADB.

Huang et al. indicated that DO was a key factor for aerobic denitrification (Xing et al., 2010). DO concentrations of $2-6 \mathrm{mg} / \mathrm{L}$ were beneficial for the growth of aerobic bacteria and the denitrification performance. As a result of the coexistence of aerobic respiration and the denitrifying reductase in one system, both $\mathrm{O}_{2}$ and $\mathrm{NO}_{\mathrm{x}}^{-}$were indispensable for the growth of ADB and were used as electron acceptors. Therefore, at the high DO levels in this study (3.0-4.2 mg/L), the activity of ADB improved, and the denitrification performance of $\mathrm{ADB}$ was enhanced. The results that showed that the production of $\mathrm{N}_{2} \mathrm{O}$ and the TN removal efficiency were higher with a $50 \Omega$ external resistance than with a $100 \Omega$ resistance at high levels of DO demonstrated that electrode denitrification with $\mathrm{ADB}$ occurred in the cathode of the MFC.

\section{CONCLUSIONS}

The increase of DO resulted in a change in the predominant species from thermophilic autotrophic nitrifiers and facultative heterotrophic denitrifiers at low DO levels to thermophilic ADB at high DO levels in the cathode of the MFC. The predominant phylum changed from Firmicutes to Proteobacteria, and the predominant class changed from Bacilli to Alpha, Beta, and Gamma Proteobacteria.

\section{REFERENCES}

Bell, L. C., and Ferguson, S. J. (1991). Nitric and nitrous oxide reductases are active under aerobic conditions in cells of Thiosphaera pantotropha. Biochem. J. 273, 423-427. doi: 10.1042/bj2730423

Chen, F., Xia, Q., and Ju, L. K. (2003). Aerobic denitrification of Pseudomonas aeruginosa monitored by online $\mathrm{NAD}(\mathrm{P}) \mathrm{H}$ fluorescence. Appl. Environ. Microbiol. 69, 6715-6722. doi: 10.1128/AEM.69.11.6715-6722.2003

Cihan, A. C., Cokmus, C., Koc, M., and Ozcan, B. (2014). Anoxybacillus calidus sp. nov., a thermophilic bacterium isolated from soil near a thermal power plant. Int. J. Syst. Evol. Microbiol. 64(Pt 1), 211-219. doi: 10.1099/ijs.0.056549-0

Clesceri, L., Greenberg, A. E., and Eaton, A. D. (1998). Standard Methods for the Examination of Water and Wastewater, 20th Edn. Washington, DC: American Public Health Association.

Feng, C., Huang, L., Yu, H., Yi, X., and Wei, C. (2015). Simultaneous phenol removal, nitrification and denitrification using microbial fuel cell technology. Water Res. 76, 160-170. doi: 10.1016/j.watres.2015.03.001

Ferguson, S. J. (1994). Denitrification and its control. Antonie Van Leeuwenhoek. 66, 89-110. doi: 10.1007/BF00871634

Fortina, M. G., Pukall, R., Schumann, P., Mora, D., Parini, C., Manachini, P. L., et al. (2001). Ureibacillus gen. nov., a new genus to accommodate Bacillus thermosphaericus (Andersson et al. 1995), emendation of Ureibacillus thermosphaericus and description of Ureibacillus terrenus sp. nov. Int. J. Syst. Evol. Microbiol. 51, 447-455. doi: 10.1099/00207713-51-2-447

Gumaelius, L., Magnusson, G., Pettersson, B., and Dalhammar, G. (2001). Comamonas denitrificans sp. nov., an efficient denitrifying bacterium isolated from activated sludge. Int. J. Syst. Evol. Microbiol. 51, 999-1006. doi: 10.1099/00207713-51-3-999

He, Z., Kan, J., Wang, Y., Huang, Y., Mansfeld, F., and Nealson, K. H. (2009). Electricity production coupled to ammonium in a microbial fuel cell. Environ. Sci. Technol. 43, 3391-3397. doi: 10.1021/es803492c

Hiraishi, A., Sugiyama, J., and Shin, Y. K. (1995). Brachymonas denitrificans gen. nov., sp. nov., an aerobic chemoorganotrophic bacterium which contains rhodoquinones, and evolutionary relationships of rhodoquinone producers
ADB is beneficial for achieving higher MFC voltages under high DO conditions, while traditional heterotrophic denitrification is conducive to higher TN removal under low DO conditions.

SND in the aeration cathode of the MFC may be beneficial for the growth of $\mathrm{ADB}$.

\section{AUTHOR CONTRIBUTIONS}

JZ conceived and designed the experiments, and JW and SW performed the experiments. JW analyzed the data and wrote the paper, and JZ, SW, XL, BH, and XD reviewed and edited the manuscript. All of the authors approved the manuscript to be published and agreed to be accountable for all aspects of the work and for questions related to the accuracy of the results.

\section{ACKNOWLEDGMENTS}

This study was supported by the Shaanxi Province Science and Technology Development Program (2014K15-03-02).

\section{SUPPLEMENTARY MATERIAL}

The Supplementary Material for this article can be found online at: http://journal.frontiersin.org/article/10.3389/fmicb. 2017.00009/full\#supplementary-material

to bacterial species with various quinone classes. J. Gen. Appl. Microbiol. 41, 99-117. doi: 10.2323/jgam.41.99

Huang, H. K., and Tseng, S. K. (2001). Nitrate reduction by Citrobacter diversus under aerobic environment. Appl. Microbiol. Biotechnol. 55, 90-94. doi: $10.1007 / \mathrm{s} 002530000363$

Huang, X., Li, W., Zhang, D., and Qin, W. (2013). Ammonium removal by a novel oligotrophic Acinetbacter sp. Y16 capable of heterotrophic nitrificationaerobic denitrification at low temperature. Bioresour. Technol. 146, 44-50. doi: 10.1016/j.biortech.2013.07.046

Hwang, C. Y., and Cho, B. C. (2008). Cucumibacter marinus gen. nov., sp. nov., a marine bacterium in the family Hyphomicrobiaceae. Int. J. Syst. Evol. Microbiol. 58, 1591-1597. doi: 10.1099/ijs.0.65587-0

Iino, T., Mori, K., Uchino, Y., Nakagawa, T., Harayama, S., and Suzuki, K. (2010). Ignavibacterium album gen. nov., sp. nov., a moderately thermophilic anaerobic bacterium isolated from microbial mats at a terrestrial hot spring and proposal of Ignavibacteria classis nov., for a novel lineage at the periphery of green sulfur bacteria. Int. J. Syst. Evol. Microbiol. 60, 1376-1382. doi: 10.1099/ijs.0.012484-0

Inan, K., Belduz, A. O., and Canakci, S. (2013). Anoxybacillus kaynarcensis sp. nov., a moderately thermophilic, xylanase producing bacterium. J. Basic Microbiol. 53, 410-419. doi: 10.1002/jobm.201100638

Janicek, A., Fan, Y., and Liu, H. (2014). Design of microbial fuel cells for practical application: a review and analysis of scale-up studies. Biofuels 5, 79-92. doi: $10.4155 /$ bfs.13.69

Jin, H. M., Kim, J. M., and Jeon, C. O. (2013). Aquamicrobium aestuarii sp. nov., a marine bacterium isolated from a tidal flat. Int. J. Syst. Evol. Microbiol. 63(Pt 11), 4012-4017. doi: 10.1099/ijs.0.048561-0

Kim, J. K., Park, K. J., Cho, K. S., Nam, S. W., Park, T. J., and Bajpai, R. (2005). Aerobic nitrification-denitrification by heterotrophic Bacillus strains. Bioresour. Technol. 96, 1897-1906. doi: 10.1016/j.biortech.2005.01.040

Kim, Y. O., Kim, H. K., Bae, K. S., Yu, J. H., and Oh, T. K. (1998). Purification and properties of a thermostable phytase from Bacillus sp. DSll. Enzyme Microb. Technol. 22, 2-7. doi: 10.1016/S0141-0229(97) 00096-3 
Kuntke, P., Smiech, K. M., Bruning, H., Zeeman, G., Saakes, M., Sleutels, T. H., et al. (2012). Ammonium recovery and energy production from urine by a microbial fuel cell. Water Res. 46, 2627-2636. doi: 10.1016/j.watres.2012.02.025

Kwon, K. K., Woo, J. H., Yang, S. H., Kang, J. H., Kang, S. G., Kim, S. J., et al. (2007). Altererythrobacter epoxidivorans gen. nov., sp. nov., an epoxide hydrolase-active, mesophilic marine bacterium isolated from coldseep sediment, and reclassification of Erythrobacter luteolus Yoon et al. 2005 as Altererythrobacter luteolus comb. nov. Int. J. Syst. Evol. Microbiol. 57, 2207-2211. doi: 10.1099/ijs.0.64863-0

Li, C., Yang, J., Wang, X., Wang, E., Li, B., He, R., et al. (2015). Removal of nitrogen by heterotrophic nitrification-aerobic denitrification of a phosphate accumulating bacterium Pseudomonas stutzeri YG-24. Bioresour. Technol. 182, 18-25. doi: 10.1016/j.biortech.2015.01.100

Li, W. W., Yu, H. Q., and He, Z. (2014). Towards sustainable wastewater treatment by using microbial fuel cells-centered technologies. Energy Environ. Sci. 7, 911-924. doi: 10.1039/c3ee43106a

Nemec, A., Musílek, M., Maixnerová, M., De Baere, T., van der Reijden, T. J., Vaneechoutte, M., et al. (2009). Acinetobacter beijerinckii sp. nov. and Acinetobacter gyllenbergii sp. nov., haemolytic organisms isolated from humans. Int. J. Syst. Evol. Microbiol. 59, 118-124. doi: 10.1099/ijs.0.001230-0

Papen, H., and Von Berg, R. (1998). A most probable number method (MPN) for the estimation of cell numbers of heterotrophic nitrifying bacteria in soil. Plant Soil 199, 123-130. doi: 10.1023/A:1004243810473

Poli, A., Romano, I., Caliendo, G., Nicolaus, G., Orlando, P., Falco, A. D., et al. (2006). Geobacillus toebii subsp. decanicus subsp. nov., a hydrocarbondegrading, heavy metal resistant bacterium from hot compost. J. Gen. Appl. Microbiol. 52, 223-234. doi: 10.2323/jgam.52.223

Robertson, L. A., and Kuenen, J. G. (1983). Thiosphaera pantotropha gen. nov. sp. nov. a facultatively anaerobic facultatively autotrophic sulphur bacterium. J. Gen. Microbiol. 129, 2847-2855. doi: 10.1099/00221287-129-9-2847

Robertson, L. A., and Kuenen, J. G. (1984). Aerobic denitrification: a controversy revived. Arch. Microbiol. 139, 351-354. doi: 10.1007/BF00408378

Robertson, L. A., van Niel, E. W. J., Torremans, R. A. M., and Kuenen, J. G. (1988). Simultaneous nitrification and denitrification in aerobic chemostat cultures of Thiosphaera pantotropha. Appl. Environ. Microbiol. 54, 2812-2818.

Roh, S. W., Nam, Y. D., Chang, H. W., Kim, K. H., Kim, M. S., Oh, H. M., et al. (2009). Alishewanella aestuarii sp. nov., isolated from tidal flat sediment, and emended description of the genus Alishewanella. Int. J. Syst. Evol. Microbiol. 59(Pt 2), 421-424. doi: 10.1099/ijs.0.65643-0

Segers, P., Vancanneyt, M., Pot, B., Torck, U., Hoste, B., Dewettinck, D., et al. (1994). Classification of Pseudomonas diminuta Leifson and Hugh 1954 and Pseudomonas vesicularis Büsing, Döll, and Freytag 1953 in Brevundimonas gen. nov. as Brevundimonas diminuta comb. nov. and Brevundimonas vesicularis comb. nov., respectively. Int. J. Syst. Bacteriol. 44, 499-510. doi: 10.1099/00207713-44-3-499

Takaya, N., Catalan-Sakairi, M. A. B., Sakaguchi, Y., Kato, I., Zhou, Z., and Shoun, H. (2003). Aerobic denitrification bacteria that produce low levels of nitrous oxide. Appl. Environ. Microbiol. 69, 3152-3157. doi: 10.1128/AEM.69.6.3152-3157.2003

Virdis, B., Rabaey, K., Rozendal, R. A., Yuan, Z., and Keller, J. (2010). Simultaneous nitrification, denitrification and carbon removal in microbial fuel cells. Water Res. 44, 2970-2980. doi: 10.1016/j.watres.2010.02.022

Willson, L. P., and Bouwer, E. J. (1997). Biodegradation of aromatic compounds under mixed oxygen /denitrifying conditions: a review. J. Ind. Microbiol. Biotechnol. 18, 116-130. doi: 10.1038/sj.jim.2900288

Wrighton, K. C., Virdis, B., Clauwaert, P., Read, S. T., Daly, R. A., Boon, N., et al. (2010). Bacterial community structure corresponds to performance during cathodic nitrate reduction. ISME J. 4, 1443-1455. doi: 10.1038/ismej.2010.66

Xie, C. H., and Yokota, A. (2005). Reclassification of Alcaligenes latus strains IAM 12599T and IAM 12664 and Pseudomonas saccharophila as Azohydromonas lata gen. nov., comb. nov., Azohydromonas australica sp. nov. and Pelomonas saccharophila gen. nov., comb. nov., respectively. Int. J. Syst. Evol. Microbiol. 55, 2419-2425. doi: 10.1099/ijs.0.63733-0

Xing, D., Cheng, S., Logan, B. E., and Regan, J. M. (2010). Isolation of the exoelectrogenic denitrifying bacterium Comamonas denitrificans based on dilution to extinction. Appl. Microbiol. Biotechnol. 85, 1575-1587. doi: 10.1007/s00253-009-2240-0

Yamada, T., Sekiguchi, Y., Hanada, S., Imachi, H., Ohashi, A., Harada, H., et al. (2006). Anaerolinea thermolimosa sp. nov., Levilinea saccharolytica gen. nov., sp. nov. and Leptolinea tardivitalis gen. nov., sp. nov., novel filamentous anaerobes, and description of the new classes Anaerolineae classis nov. and Caldilineae classis nov. in the bacterial phylum Chloroflex. Int. J. Syst. Evol. Microbiol. 56, 1331-1340. doi: 10.1099/ijs.0.64169-0

Zhang, Y., and Angelidaki, I. (2012). Bioelectrode-based approach for enhancing nitrate and nitrite removal and electricity generation from eutrophic lakes. Water Res. 46, 6445-6453. doi: 10.1016/j.watres.2012.09.022

Zhang, Y., and Angelidaki, I. (2013). A new method for in situ nitrate removal from groundwater using submerged microbial desalination denitrification cell (SMDDC). Water Res. 47, 1827-1836. doi: 10.1016/j.watres.2013.01.005

Zhang, Y., and Angelidaki, I. (2015). Submersible microbial desalination cell for simultaneous ammonia recovery and electricity production from anaerobic reactors containing high levels of ammonia. Bioresour. Technol. 177, 233-239. doi: 10.1016/j.biortech.2014.11.079

Conflict of Interest Statement: The authors declare that the research was conducted in the absence of any commercial or financial relationships that could be construed as a potential conflict of interest.

Copyright (c) 2017 Zhao, Wu, Li, Wang, Hu and Ding. This is an open-access article distributed under the terms of the Creative Commons Attribution License (CC BY). The use, distribution or reproduction in other forums is permitted, provided the original author(s) or licensor are credited and that the original publication in this journal is cited, in accordance with accepted academic practice. No use, distribution or reproduction is permitted which does not comply with these terms. 